DOI: 10.17707/AgricultForest.62.4.09

\author{
Irina MITROFANOVA, Valentina BRAILKO, \\ Nina LESNIKOVA-SEDOSHENKO, \\ Olga MITROFANOVA ${ }^{1}$
}

\title{
CLONAL MICROPROPAGATION AND SOME PHYSIOLOGY ASPECTS OF ESSENTIAL OIL ROSES VALUABLE CULTIVARS REGENERATION IN VITRO
}

\begin{abstract}
SUMMARY
Limiting factor for vegetative propagation of essential oil roses is their high rate of viral pathogens damages. Complex system of plants diagnostics, cleaning up and propagation in vitro gives possibility to obtain high quality plant material.

This study aimed to investigate some features of in vitro meristem culture in essential oil rose cultivars Festivalnaya, Raduga, Lany, Kooperatorka, Michurinka, Iskra and to evaluate morphological, anatomical and physiological parameters of plants in vitro. For induction of microshoot regeneration and leaf formation explants we cultured MS medium with 0.5-1.5 $\mathrm{mg} \mathrm{l}^{-1} \mathrm{BAP}, 30 \mathrm{~g} \mathrm{l}^{-1}$ sucrose, $8 \mathrm{~g} \mathrm{l}^{-1}$ agar. For in vitro chemotherapy, Ribavirin was added to the media. It was found out that February and March were the optimum time for meristem isolation and development. The maximum length of regenerated microshoots was observed in the cultivars Iskra and Kooperatorka at the initial stage of cultivation. Cultivar Festivalnaya was characterized by high multiplication rate (1:5-1:6). Due to the maximum number of leaves per shoot, the minimum leaf shape index, anatomical characteristics of palisade tissue development, the number of chloroplasts in photosynthetic tissue cells, and the rate of vascular bundle sheath development the cultivar Festivalnaya were selected. However, the maximum integral index of photosynthetic activity and viability index were noticed in regenerants of Lany cultivar. Analysis of chlorophyll $a$ fluorescence rate indicated that physiological state of leaves was normal in all investigated in vitro regenerants.

Keywords: Rosa damascena Mill., Rosa gallica L., meristem, clonal micropropagation, morpho-anatomy characteristic of leaf, fluorescence.

\section{INTRODUCTION}

Rose (genus Rosa L., family Rosaceae Juss.) is one of the most valuable essential oil plants cultivated on the south of Russia. Due to its high quality and unique aroma, rose oil is widely used in perfumery and cosmetics,

\footnotetext{
${ }^{1}$ Irina Mitrofanova, (corresponding author: irimitrofanova@yandex.ru),Valentina Brailko, Nina Lesnikova-Sedoshenko, Olga Mitrofanova, Nikita Botanical Gardens- National Scientific Center, Nikita, Yalta, 298648, RUSSIA.

Paper presented at the $7^{\text {th }}$ International Scientific Agricultural Symposium "AGROSYM 2016".

Notes: The authors declare that they have no conflicts of interest. Authorship Form signed online.
} 
pharmaceutical and food industries. Its antibacterial, antifungal and antidepressant properties are used in medicine.

In Russia, introduction and breeding of aromatic roses are closely related to Nikita Botanical Gardens. In the first years of its foundation (1815-1816) Kazanlak Rose (Rosa damascena var. trigintipetala) was introduced. Industrial plantings of essential oil rose were set in the Crimea at the end of the XIX century. Research works on the essential oil roses was launched in 1923 and the first rose collection was created. However, over the last 20 years, most of essential oil rose plantations in the Crimea had been destroyed by anthropogenic factor and plant pathogens. Currently, essential oil rose collection in Nikita Botanical Gardens is being restored and it includes 2 species and 12 cultivars. Traditional methods of propagation and producing high quality healthy planting material of essential oil rose, as well as ornamental roses, are cumbersome and ineffective. In such propagation methods viral, bacterial and fungal diseases are usually transferred from plant to plant. For plants of the genus Rosa L. the most common and harmful viruses are Prunus necrotic ringspot ilarvirus (PNRSV), Apple mosaic ilarvirus (ApMV), Arabis mosaic nepovirus (ArMV) (Golino et al., 2007). Thus, method of clonal micropropagation is becoming an increasingly popular as an alternative to vegetative propagation of roses (Mitrofanov et al., 2015).

The aim of this work was to study in vitro regeneration characteristics of essential oil rose cultivars and evaluation of morphological, anatomical and physiological parameters of regenerants in the process of clonal micropropagation in vitro.

\section{MATERIAL AND METHODS}

Investigations were carried out in the Department of Plant Developmental Biology, Biotechnology and Biosafety in Nikita Botanical Gardens from January 2015 to April 2016. Shoots with buds were collected from a pre-tested by ELISA-test and PCR analysis visually symptomless virus-free 5-year-old plants of essential oil rose from the collection of the Nikita Botanical Gardens. The materials for the research were cultivars Festivalnaya (Rosa damascena Mill. $\mathrm{x}$ Rosa gallica L.), Raduga ( $R$. gallica subsp. eriosila Kell. var. austriaca $\mathrm{Br}$. $\mathrm{x}$. gallica), Lany $[R$. alba L. x ( $R$. damascena $\times$ $R$. gallica $)]$, Kooperatorka $(R$. damascena $\mathrm{x} R$. gallica), Michurinka ( $R$. damascena $\mathrm{x} R$. gallica) and Iskra (Bulgarian cultivar).

Studies on in vitro culture were carried out according to the procedures presented by Kyte (2013) and Mitrofanova (2011). Stems were exempted from leaves and spikes, and washed in running tap water for $30 \mathrm{~min}$., and then they were cut into segments with one bud, considering their position on the shoot (top, middle, bottom zones). Explants were sterilized for 30 seconds in $70 \%$ ethanol, 7 10 minutes in $1 \%$ Thimerosal (Sigma, USA), $15-17 \mathrm{~min}$ in $2-3 \% \mathrm{NaOCl}$ solution with 2-3 drops of Tween-20 detergent. After each reagent explants were washed 34 times in sterile distilled water. Meristems $0.2-0.5 \mathrm{~mm}$ length were isolated from 
vegetative buds under binocular microscope SMZ745T (Nikon, Japan). For morphogenesis induction meristems were placed into the culture vessels with MS medium (Murashige, Skoog, 1962) with $0.1 \mathrm{mg} \mathrm{l}^{-1} \alpha$-naphthylacetic acid (NAA), $0.5 \mathrm{mg} \mathrm{l}^{-1}$ gibberellic acid $\left(\mathrm{GA}_{3}\right), 0 ; 0.5 ; 1.0 ; 1.5 \mathrm{mg} \mathrm{l}^{-1}$ 6-benzylaminopurine (BAP), $30 \mathrm{~g} \mathrm{l}^{-1}$ sucrose and $8 \mathrm{~g} \mathrm{l}^{-1}$ agar (Agar-agar, Panreac). $\mathrm{pH}$ was adjusted to 5.6 with $1 \mathrm{~N} \mathrm{NaOH}$ solution. Ribavirin (virazole, 1-beta-D-ribofuranosyl-1H-1,2,4triazole-carboxamide, Sigma, USA) was used at $5 \mathrm{mg} \mathrm{l}^{-1}$ for elimination of possible viral infection. Culture media were autoclaved at $121^{\circ} \mathrm{C}$ for $15-20$ minutes. $\mathrm{GA}_{3}$ was added to the medium after autoclaving. The culture vessels were maintained in a climate chamber (Panasonic MLR-352-PE) at the temperature $24^{\circ} \mathrm{C}$, 16 -hour photoperiod under cool white fluorescent lamps (Philips TL, 40W) with an intensity $37.5 \mu \mathrm{mol} \mathrm{m} \mathrm{m}^{-2} \mathrm{~s}^{-1}$. Each treatment was tested three times with ten replications. To induce rooting, microshoots $1.5-2.0 \mathrm{~cm}$ length were transferred to $1 / 2$ MS medium for rhizogenesis supplemented with $0.0,0.5,0.75,1.0,1.5,2.0$ $\mathrm{mg}^{-1}$ indole-3-butyric acid (IBA). Culture medium was injected with nanomaterials - potassium humate or sodium humate. After 4-6 weeks, the percentage of in vitro rooted microshoots, number of root/shoot and root length was measured.

To determine microshoot proportions 3-5 plants of each cultivar were taken, leaf morphometry for leaf shape index calculation was performed in 10 replications (Zlobin et al., 2009). Anatomic slides were prepared by the standard technique. Histological and anatomical studies of three essential oil rose cultivars (Raduga, Lany, Festivalnaya) were carried out under the light microscope AxioScope A.1 (Zeiss, Germany) using software Axio Vision Rel. 4.8.2.

Parameters of photosynthetic activity (FA) were measured with portable fluorometer "Florotest" (Institute of Cybernetics. Glushkov National Academy of Sciences of Ukraine, 2010). During the experiments, the following parameters were recorded: the initial level of fluorescence after irradiation $\left(\mathrm{F}_{0}\right)$, maximum $\left(\mathrm{F}_{\mathrm{m}}\right)$ and stationary $\left(\mathrm{F}_{\mathrm{st}}\right)$ fluorescence values after light adaptation. We calculated vitality index and photosynthetic activity - relative quantum efficiency of photosystem 2 (Bajron et al, 2000; Stirbet, Govindjee, 2011).

\section{RESULTS AND DISCUSSION}

The results of our investigations demonstrated that viability of isolated meristems in six essential oil rose cultivars and their development under in vitro conditions depended on the genotype, terms of material collecting, sterilization conditions, type and concentration of plant growth regulators in the culture medium. On the Southern Coast of the Crimea the best terms of explant collecting and introduction of the isolated meristem to in vitro conditions were February-April and June. During this period, number of developing meristems was high in all the studied cultivars and reached 94.6\% in 'Festivalnaya', $85.6 \%$ in 'Iskra', 84.4\% in 'Raduga', $83.7 \%$ in 'Lany', $81.2 \%$ in 'Kooperatorka' and 80.9 $\%$ in 'Michurinka'. In September and October number of in vitro developing meristems was significantly lower (34-37\%). Sterilization yielded $87.5 \%$ of 
explants free of contamination.

Initiation of meristem development in the studied cultivars was noticed after 7 days culture on MS medium supplemented with $0.5,1.0,1.25,1.5 \mathrm{mg}^{-1} \mathrm{BAP}$, $0.1 \mathrm{mg} \mathrm{l}^{-1} \mathrm{NAA}, 0.5 \mathrm{mg} \mathrm{l}^{-1} \mathrm{GA}_{3}$. Meristems of the cultivars Lany, Michurinka and Kooperatorka developed more actively on the medium with $1.0 \mathrm{mg} \mathrm{l}^{-1}$ BAP. BAP concentration $1.5 \mathrm{mg} \mathrm{l}^{-1}$ was optimal for the cultivars Iskra, Raduga and Festivalnaya. In the control (medium without cytokinins) explants developed poorly and died after 21 days of culture. Meristems isolated from vegetative buds of the upper and middle zones of the shoots had high regenerative capacity. $\mathrm{GA}_{3}$ supplemented to the medium containing BAP intensified regeneration that is corresponds to the data presented by P.K. Pati et al. (2006), A. Ginova et al. (2012). After 21 days of culture on the media supplemented with BAP regeneration of one microshoot with 1-4 compound leaves was noticed in all the studied cultivars. Those shoots were transferred to the fresh medium.

Induction of multiple shoot formation and microshoot length in essential oil rose were largely dependent on BAP and NAA concentrations in the culture medium. Active microshoot elongation was observed in the cultivars Iskra and Kooperatorka at BAP concentration 1.25 and $1.0 \mathrm{mg} \mathrm{l}^{-1}$, respectively.

It is known that BAP, as an exogenous cytokinin added to the medium, reduces apical dominance and induces axillary bud development in roses (Kapchina et al., 2000). The effect of BAP concentrations 0.5, 1.0, 1.25 and $1.5 \mathrm{mg} \mathrm{l}^{-1}$ on axillary microshoots induction has been studied. Initiation of multiple shoot formation in essential oil rose cultivars was observed after the third subculture. Axillary buds and microshoots formation was observed on the medium with $1.0 \mathrm{mg}$ $1^{-1}$ BAP in the cultivars Lany, Michurinka, Kooperatorka after the fourth subculture and for the cultivars Iskra, Raduga and Festivalnaya the best concentrations were 1.25 and $1.5 \mathrm{mg} \mathrm{l}^{-1}$. In this condition the multiplication index was maximum. In the cultivar Festivalnaya multiplication index was 1:6-1:10 (Fig. 1C). In the cultivars Iskra, Michurinka and Kooperatorka multiplication index did not exceed 1:8 (Fig. 1A), in Raduga and Lany - 1:7 (Fig. 1B). However, under increasing BAP concentration from 2.0 to $4.0 \mathrm{mg} \mathrm{l}^{-1}$ and further subcultures we noticed reduction of regenerative capacity that is corresponds to the data presented by N. Hameed et al. (2006).

One of the most problems in essential oil roses in vitro propagation is rooting (Pati et al, 2006; Ginova et al, 2012.). In the process of micropropagation we observed spontaneous microshoot rooting in the cultivars Raduga and Festivalnaya, which is treated as a "hormonal autonomy" of plant cells in vitro (Hamburg et al., 1974). To get complete regenerants microshoots were placed on the rooting medium. We used 1/2 MS medium 0.75-2.0 $\mathrm{mg} \mathrm{l}^{-1}$ IBA. High IBA concentrations resulted in callus formation at the base of microshoots and single roots development. Induction of normal roots 1.5-2.0 cm length was observed on $1 / 2 \mathrm{MS}$ medium with $0.75 \mathrm{mg} \mathrm{l}^{-1} \mathrm{IBA}$. 


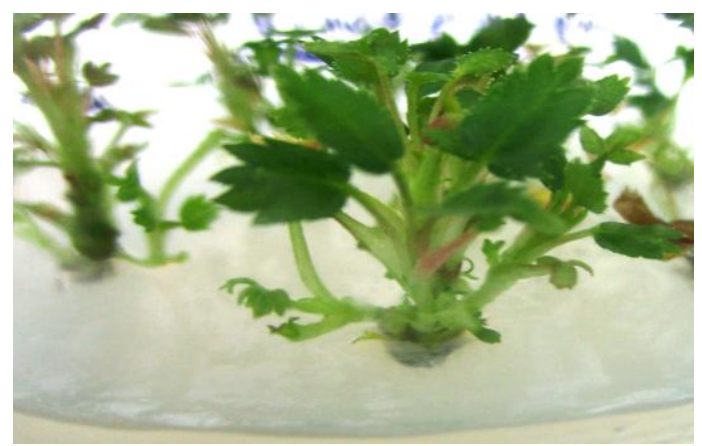

A

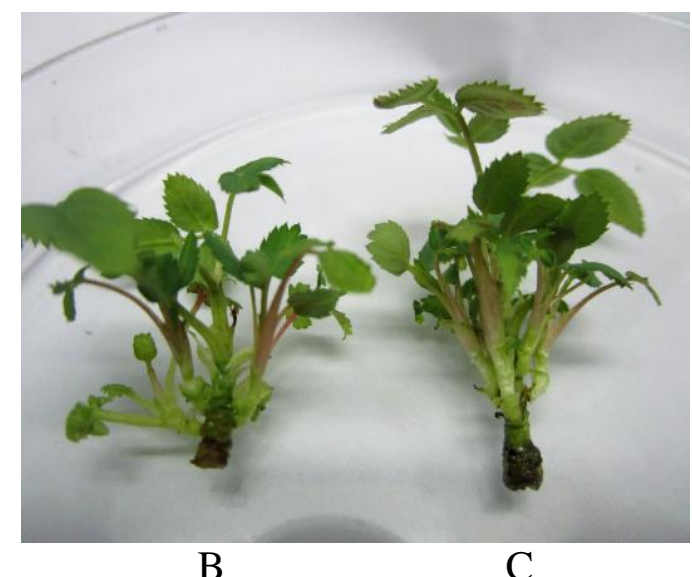

B

$\mathrm{C}$

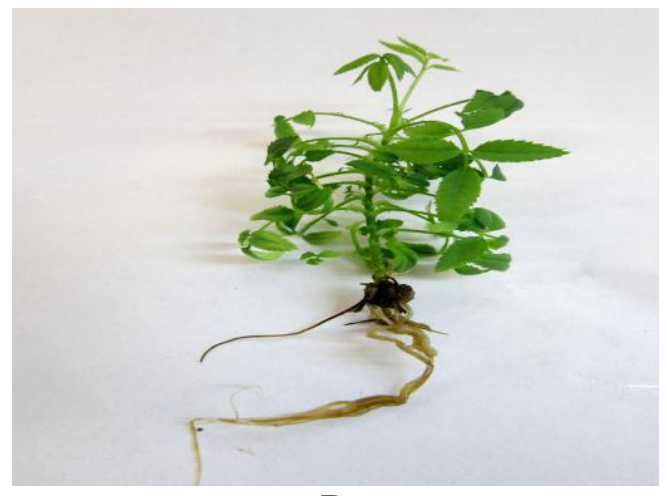

$\mathrm{D}$

Figure 1. Active shoot formation in essential oil rose cultivars: A - Iskra, B - Raduga, C - Festivalnaya; D - regenerant of the cultivar Lany (bar $1 \mathrm{~cm}$ )

In the cultivars Iskra and Kooperatorka number of microshoots rooted in vitro was $68 \%$ and $70 \%$, respectively. High rooting percentage was obtained on $1 / 2 \mathrm{MS}$ medium with $0.75 \mathrm{mg} \mathrm{l}^{-1}$ IBA and $1.0 \mathrm{~g} \mathrm{l}^{-1}$ potassium and sodium humate. 
Herewith, in cultivar Festivalnaya number of rooted microshoots was up to $84 \%$, Raduga - 78\%, Michurinka - 75\% and Lany - 74\% (Fig. 1D). In the cultivar Festivalnaya microshoots formed 4-6 roots $4.0-6.0 \mathrm{~cm}$ long, in Michurinka cultivar - from 2 to 4 roots $2.5-4.0 \mathrm{~cm}$ long, in Raduga - 6-8 roots $0.5-2.5 \mathrm{~cm}$ long, in Lany - from 4 to 6 roots $3.0-5.0 \mathrm{~cm}$ long. Regenerants were transferred to adaptation ex vitro.

Cultivated rose regenerants under in vitro conditions were $2.4-5.6 \mathrm{~cm}$ height. Data comparisong in that index demonstrated that maximum microshoot height $(3.6-4.2 \mathrm{~cm})$ was characteristic for Lany cultivar and the shortest microshoots $(2.4-3.2 \mathrm{~cm})$ were noticed in Raduga cultivar.

To estimate morphogenic capacity of essential oil rose cultivars under in vitro conditions we analyzed the amount and size of formed leaves. It was found out that cultivars Raduga, Iskra and Festivalnaya formed by an average from 4 to 7 leaves per microshoot. Leaves were ternate, pinnate venation, leaf edge toothed. Large leaves $(0.63 \times 0.87 \mathrm{~cm})$ and maximum leaf shape index $(0.73)$ was characteristic of Lany cultivar. Number of leaves facilitated improvement of the studied cultivars plasticity and their further adaptation to different factors of culture. These results are in agreement with the research findings by E.B. Kirichenko and his colleagues (1993).

For structural analysis, leaves from regenerants cultivated on the optimized Murashige and Skoog medium with $1.5 \mathrm{mg}^{-1}$ BAP for 4 months were collected. Leaf blades in essential oil rose under in vitro conditions were bifacial and they had both general and specific anatomical characteristics. The leaves were thin, their average thickness was 79-122 $\mu \mathrm{m}$ (Table 1).

Table 1. Quantitative indexes of leaf anatomical structure in some essential oil rose cultivars in vitro $(\mathrm{M} \pm \mathrm{SE}, \mu \mathrm{m})$.

\begin{tabular}{|c|c|c|c|c|}
\hline \multirow{2}{*}{\multicolumn{2}{|c|}{ Anatomical structure indexes }} & \multicolumn{3}{|c|}{ Cultivar } \\
\hline & & Raduga & Festivalnaya & Lany \\
\hline \multicolumn{2}{|c|}{ Leaf blade thickness } & $121.52 \pm 19.69$ & $107.69 \pm 4.22$ & $79.30 \pm 9.35$ \\
\hline $\begin{array}{l}\text { Epidermis } \\
\text { thickness }\end{array}$ & $\begin{array}{l}\text { Adaxial } \\
\text { Abaxial }\end{array}$ & $\begin{array}{l}13.70 \pm 1.24 \\
15.89 \pm 1.19\end{array}$ & $\begin{array}{l}12.56 \pm 0.60 \\
12.01 \pm 0.78\end{array}$ & $\begin{array}{c}11.83 \pm 0.51 \\
9.85 \pm 0.97\end{array}$ \\
\hline \multirow{2}{*}{$\begin{array}{c}\text { Mesophyll } \\
\text { thickness }\end{array}$} & Palisade & $34.58 \pm 8.28$ & $37.24 \pm 4.55$ & $20.11 \pm 3.11$ \\
\hline & Spongy & $57.28 \pm 12.83$ & $38.09 \pm 4.69$ & $36.03 \pm 5.43$ \\
\hline \multicolumn{2}{|c|}{ Palisade index } & 0.37 & 0.50 & 0.36 \\
\hline \multicolumn{5}{|c|}{ Indexes of leaf blade epidermis anatomy } \\
\hline $\begin{array}{l}\text { Epidermal } \\
\text { cells size }\end{array}$ & $\begin{array}{l}\text { Adaxial } \\
\text { Abaxial }\end{array}$ & $\begin{array}{l}27 \times 18 \\
20 \times 17\end{array}$ & $\begin{array}{l}27 \times 16 \\
30 \times 15 \\
\end{array}$ & $\begin{array}{c}21 \times 19 \\
27 \times 5 \\
\end{array}$ \\
\hline \multicolumn{2}{|c|}{ Stoma pore size (length×width) } & $19 \times 5$ & $20 \times 7$ & $19 \times 8$ \\
\hline \multicolumn{2}{|c|}{ Stomata number per $1 \mathrm{~mm}^{2}$ surface } & $87.78 \pm 15.50$ & $79.82 \pm 4.00$ & $76.61 \pm 5.63$ \\
\hline
\end{tabular}


Common to all the studied samples were single-layer epidermis, hypostomatic type, stomatal apparatus was of anomocytic type. Adaxial epidermal cells were larger than abaxial ones and of irregular flexuous shape. Cuticular layer was thin $(1-3 \mu \mathrm{m})$, glandular hairs absent. Adaxial epidermis thickness was equal or slightly greater than the thickness of abaxial one. Analysis of leaf covering tissues molds made immediately after the opening of the culture vessels demonstrated that most of stomata were open. According to the degree stomatal apparatus activity studied cultivars can be divided as follows: over $85 \%$ of open stomata in leaves of Lany cultivar, 60-85\% - in Raduga and Festivalnaya.

Mesophyll was bilateral, cells of palisade and spongy tissues located loosely. One (rarely two) layers of cylindrical cells formed palisade mesophyll. Spongy mesophyll in the studied essential oil rose cultivars consisted of two or three layers of elongated or round-shaped cells. Chloroplasts arrangement in chlorenchyma cells was diffuse or line trim, they were oval shaped, their amount: 8-19 units/cell. Spongy parenchyma thickness in all studied cultivars was greater than palisade one thickness. In the cultivar Lany, despite reduced thickness of the sponge layer, the cells were arranged more compact, and number of layers was up to 4 . There were significant differences between cultivars in the thickness of palisade mesophyll. Thus, one or two-row leaf palisade tissue in the cultivar Festivalnaya provided maximum palisade index $(0.50)$, which represented the ratio of palisade thickness to the total mesophyll.

The main vein of the leaf was a closed collateral beam. Xylem vessels were arranged in regular rows, surrounded by mechanical and parenchymal plates, in the cultivars Raduga and Festivalnaya at the top and bottom of the beam initials of corner collenchyma were noticed (Fig. 2). Stomata were small, their length was 19.00-20.14 $\mu \mathrm{m}$. Stomata number per unit area $\left(1 \mathrm{~mm}^{2}\right)$ did not demonstrate any significant differences between the studied cultivars, but the highest number of stomata was observed in the cultivar Raduga $(87.78 \pm 15.50$ stomata $/ \mathrm{mm}^{2}$ ). E. Bunning and H. Sagromsky (1948) supposed that stomata functioning under aseptic culture was flawed due to disturbances in the mechanism of their opening and closing. Changes in culture conditions facilitated stomata closure (Smith et al., 1986). Thus, smaller stomata number may indicate lower evaporation of water, on the one hand, and on the other - low ability to regulate transpiration under hydrothermal and light stress, which can be triggered by adaptation of regenerants to in vivo conditions.
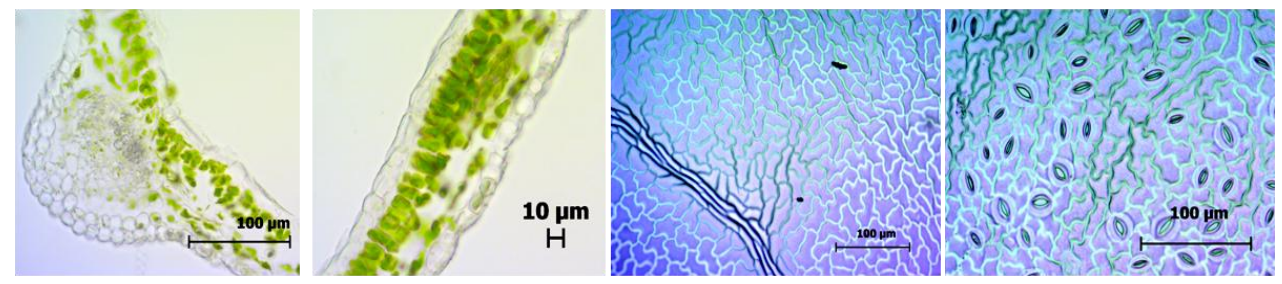

Fig. 2. Structure of leaf in cultivar Festivalnaya in vitro 
Plants adaptation to the culture conditions resulted in required intensity of productive processes (Stirbet, A., Govindjee, 2011). Photosynthetic activity is closely related to quantitative indexes plastid apparatus functioning. It can be determined by the method of chlorophyll fluorescence induction (CFI) based on Kautsky curve analyses.

Fluorescent signal increase from $F_{0}$ to $F_{m}$ denoted in the values of variable fluorescence $\left(\mathrm{F}_{\mathrm{v}}\right)$. Its relation to the maximum level $\left(\mathrm{F}_{\mathrm{m}}\right)$ indicates photoinhibition at the level of light-harvesting complexes of photosystem 2 (Stirbet, A., Govindjee, 2011). Values of this index in the studied cultivars were in the normal range (from 0.53 relative units in the cultivar Lany to 0.68 - in the cultivar Raduga). Some authors (Bajron et al, 2000; Stirbet, A., Govindjee, 2011) supposed there was correlation between CFI kinetics and photosynthetic assimilation of carbon dioxide. So, photosynthetic activity can be evaluated as $\left(\mathrm{F}_{\mathrm{m}}-\mathrm{F}_{\mathrm{st}}\right) / \mathrm{F}_{\mathrm{m}}$. Normally its value is 0.6 or higher but under pathologies of different origin it reduced proportionally to the weakening of photosynthetic function (Smith et al., 2008). Viability index $-\mathrm{F}_{\mathrm{m}} / \mathrm{F}_{\mathrm{st}}$ in rose was $2.05-2.57$ relative units. All those data suggest normal functional state of the photosynthetic apparatus in the investigated rose cultivars under in vitro conditions.

\section{CONCLUSIONS}

Morphogenetic potential was studied and the way of direct microshoot regeneration from the meristems was demonstrated for 6 essential oil rose cultivars. Possibility of multiple shoot formation, depending on the genotype and hormone factors was revealed. Significance of BAP and $\mathrm{GA}_{3}$ for the induction of microshoot development and regeneration was determined. It was found that complex use of humates and IBA in 1/2 MS medium increased rooting efficiency and quality of roots.

Morphological, anatomical and physiological studies essential oil rose microshoots, as a part of complex biotechnological research, revealed informative structural indexes of plant adaptability and stress-resistance. Due to its anatomical characteristics of palisade tissue, number of chloroplasts in photosynthetic tissue cells and bundle sheath sophistication cultivar Festivalnaya was selected.

Comparative analysis of chlorophyll $a$ fluorescence induction demonstrated that functional state of leaves in all studied cultivars wais normal. Maximum values of photosynthetic activity index and vitality index were observed in the cultivar Lany.

\section{ACKNOWLEDGMENT}

This study was funded by a research grant № 14-50-00079 of the Russian Science Foundation. 


\section{REFERENCES}

Bajron, O.V., Korneev, D.Ju., Snegur, O.O., Kitaev, O.I. (2000) Instrumental study of photosynthetic apparatus by chlorophyll fluorescence induction, Methodological guidelines, Kiev, 11 p.

Bunning, E., Sagromsky, H. (1948) Die Bildung des Spaltoffnungs musters in der Blattepidermis. Z. Naturf., 36, 203-216.

Hamburg, K.Z., Leonova L.A., Rekoslavskaya, N.I. (1974). Hormonal autonomous of plant cells isolated in culture. In: Growth and hormonal regulation of plant life. Irkutsk: Siber. Institute of Plant Physiology and Biochemistry SB RAS, 85-101.

Ginova, A., Tsvetkov, I., Kondakova, V. (2012). Rosa damascene Mill. - an overview for evaluation of propagation methods. Bulgarian J. Agricult. Science, 18 (4), 545556.

Golino, D.A., Sim, S.T., Cunningham, A., Rowhani, A. (2007). Transmission of rose mosaic viruses. Acta Horticulturae, 751 (1), 217-224. doi: 10.17660 / ActaHortic.2007.751.26

Hameed, N., Shabbir, A., Ali, A., Bajwa, R. (2006). In vitro micropropagation of disease free rose (Rosa indica L.). Micopath., 4 (2), 35-38.

Ivanova, L.A., Ivanov, L.A., Ronzhina, D.A., Pyankov, V.I. (2008). Structural parameters of leaf mesophyll under shading plants of different function types. Plant Physiology, 55 (2), 230-239.

Kapchina, A.V., Vanntelgen, H.J., Yakimova, E. (2000). Role of phenylurea cytokinin CPPU in apical dominance release in in vitro cultured Rosa hybrida L. J. Plant Growth Regul., 19, 232-237.

Kirichenko, E.B., Fernando, S.S., Kuzmina, T.A., Chernyadev, I.I. (1993). Organogenesis features in aromatic roses during clonal micropropagation. Bull. GBS, 167, 96-102.

Kyte, L., Kleyn, J., Scoggins, H., Bridgen, M. (2013). Plants from test tubes: An introduction of micropropagation. 4th ed. Timber Press, Portland, Oregon. 274 p.

Mitrofanova, I.V. (2011). Somatic embryogenesis and organogenesis as a base of biotechnology perennial horticultural plants obtaining and conservation. Agrarna nauka, Kiev. 344 p.

Mitrofanova, I.V., Mitrofanova, O.V., Brailko, V.A., Lesnikova-Sedoshenko, N.P. (2015). Biotechnology and physiology features of valuable genotypes of essential oil roses in vitro cultivation. Journal "Izvestia of universities. Applied chemistry and biotechnologies, 2 (13), 38-48.

Murashige, T., Skoog, F.A. (1962). Revised medium for rapid growth and bioassays with tobacco tissue culture. Physiol. Plant., 15, N 13, 473-493, http://dx.doi.org/10.1111/j.1399-3054.1962.tb08052.x

Pati, P.K., Rath, S.P., Sharma, M., Sood, A., Ahuja, P.S. (2006). In vitro propagation of rose: A review. Biotechnol. Adv., 24, 94-114.

Smith, M.A., Palta, J.P., McCown, B.H. (1986). Comparative Anatomy and Physiology of Microcultured, Seedling and Greenhouse grown Asian White Birch. J. Amer. Soc. Hort. Sci., 111, 3, 437-442.

Stirbet, A., Govindjee (2011). On the relation between the Kautsky effect (chlorophyll a fluorescence induction) and Photosystem II: Basics and applications of the OJIP fluorescence transient. J. Photochem. Photobiol. B: Biol, 104, 1-2, 236-257, doi:. 10.1016 / j.jphotobiol.2010.12.010.

Zlobin, Ju.A., Skljar, V.G., Bondareva, L.M., Kiril'chuk, K.S. (2009). Morphometric conception at modern botany. Chornomorski Botanical Journal, 5 (1), 5-22. 